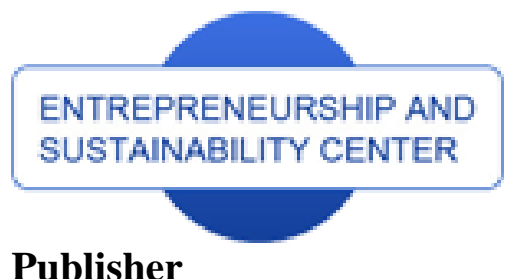

Publisher
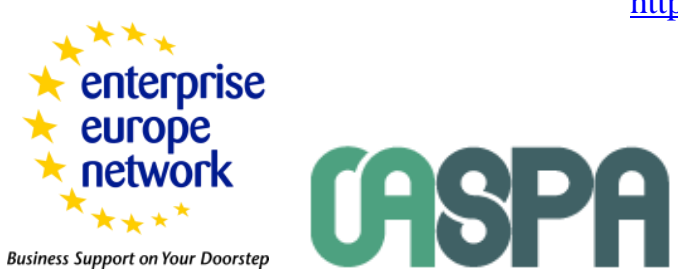

THOMSON REUTERS

Emerging Sources Citation Index WEB OF SCIENCETM

\title{
THE ASSESSMENT OF CORPORATE SOCIAL RESPONSIBILITY: APPROACHES ANALYSIS ${ }^{1}$
}

\author{
Jankalová Miriam', Jankal Radoslav² \\ ${ }^{1}$ University of Žilina, Faculty of Operation and Economics of Transport and Communications, Slovakia \\ ${ }^{2}$ University of Žilina, Faculty of Management Science and Informatics, Slovakia \\ E-mails: ${ }^{1}$ miriam.jankalova@fpedas.uniza.sk; ${ }^{2}$ radoslav.jankal@fri.uniza.sk
}

Received 20 November 2016; accepted 15 February 2017

\begin{abstract}
The problem of the last period becomes the assessment of individual areas of Corporate Social Responsibility, which is associated with a number of CSR approaches and with their "ability" to measure achieved level in every CSR item. The aim of this study is, based on a comparative analysis, to identify appropriate approach to assessing the achieved level of Corporate Social Responsibility. The study is organized as follows: the theoretical background (studies) of approaches to evaluating the CSR; the findings about primary and secondary data on structure, purpose and application of approaches to evaluating the CSR, the appropriate approach to evaluating the CSR activities of the company in the light of any previous research; conclusions in dealing with the issues and future research opportunities of the study.
\end{abstract}

Keywords: corporate social responsibility, assessment, business excellence, models, indexes, sustainability, environmental, social, economic, stakeholder, voluntariness

Reference to this paper should be made as follows: Jankalová, M.; Jankal, R. 2017. The assessment of corporate social responsibility: approaches analysis, Entrepreneurship and Sustainability Issues 4(4): 441-459. http://doi.org/10.9770/jesi.2017.4.4(4)

JEL Classifications: M14, Q56

\section{Introduction}

Corporate social responsibility comes in many different shapes and sizes which is demonstrated by many authors (Carroll, 1979; Búciová, 2008; Dahlsrud, 2008; Mutz, 2008; Gjølberg, 2009; Kuldová, 2010; Lakin and Scheubel, 2010; Remišová, 2011; Sapkauskiene and Leitoniene, 2014; Figurska, 2014; Tvaronavičienè, 2014; Raudeliūnienè, Tvaronavičienè, Dzemyda and Sepehri, 2014; Grubicka and Matuska, 2015; Baronienė and Žirgutis, 2016).

- A watershed in CSR was 1971 when the Committee for Economic Development (CED) published its Social Responsibilities of Business Corporations. As a code of conduct (Committee for Economic Development,

\footnotetext{
${ }^{1}$ The study was conducted within the project VEGA 1/0916/15 offered by The Ministry of Education, Science, Research and Sport of the Slovak Republic.
} 
1971), the CED outlined a three-tiered model of CSR: the inner circle, the intermediate circle and the outer circle. The inner circle means, that the basic responsibilities an organization has for creating profit and growth. The intermediate circle means, that an organization must be sensitive to the changing social contract that exists between business and society when it pursues its economic interests. The outer circle means, that the responsibilities and activities an organization needs to pursue towards actively improving the social environment e.g. poverty or urban crowding issues.

- Archie B. Caroll (Caroll, 1979) based his definition of CSR from the following three distinct aspects of corporate social performance (Caroll, 1979): 1. A basic definition of social responsibility, 2. An enumeration of the issues for which a social responsibility exists, 3. A specification of the philosophy of response. First (Caroll, 1979) he stated four areas of CSR - the economic, legal, ethical and discretionary. The economic component of CSR represents the fundamental social responsibility of business. The legal component recognizes the obligation of the enterprise to obey laws. The ethical responsibilities have been considerably more difficult to define and interpret. Referred to as the "grey area", this component "involves behaviors and activities that are not embodied in law but still entail performance expected of business by society's members". The fourth area of responsibilities is called discretionary or voluntary. This category of social responsibility is totally dictated by the "discretion" of the organization as there are no laws or codified expectations guiding the corporations' activities. Later Carroll (Caroll, 1991) defined this component as philanthropic because this term provides a more specific description of how this component is typically implemented in organizational practice.

- John Elkington (Elkington, 1994) and later used in his 1997 (Elkington, 1997) book "Cannibals with Forks: The Triple Bottom Line of 21st Century Business" introduced the CSR concept as "triple bottom line", consisting of three items, namely the economic, social and environmental (it consists of three Ps, also profit, people and planet). A triple bottom line measures the company's economic value, "people account" which measures the company's degree of social responsibility and the company's "planet account" - which measures the company's environmental responsibility.

- Philip Kotler and Nance Lee (Kotler and Lee, 2005) distinguished six major types of corporate social initiatives. These initiatives include ones that are marketing related (corporate cause promotions, causerelated marketing, corporate social marketing and corporate philanthropy) as well as ones that are outside the typical functions of marketing departments (i.e., employee volunteering and socially responsible business practices).

- Jana Trnková (Trnková, 2005) and Martina Prskavcová, Kateřina Maršíková, Pavla Řehořová and Magdalena Zbránková (Prskavcová, Maršíková, Řehořová and Zbránková, 2008) perceive the corporate social responsibility at three levels, namely economic, social and environmental.

- Researchers from the Ashridge Business School (Danish Commerce and Companies Agency, 2005) divided the corporate social responsibility into the following seven main groups: a) leadership, vision and values, b) marketplace activities, c) workforce activities, d) supply chain activities, e) stakeholder engagement, f) community activities, g) environmental activities.

- Alexander Dahlsrud (Dahlsrud, 2008) specified in his work "How Corporate Social Responsibility is defined: an Analysis of 37 definitions" five basic CSR items, namely the environmental, social, economic, stakeholders and voluntariness. He determined that four of these five items appear min. in $80 \%$ of definitions and moreover at least three of five items occur in as much as $97 \%$ of definitions.

- Nick Lakin, Veronica Scheubel (Lakin and Scheubel, 2010) and Gerd Mutz (Mutz, 2008) claim that the corporate responsibility is formed by three items: economic, social and environmental. As the ethical and legal responsibilities are part of every item, they do not have a separate place.

- The approach of Zuzana Búciová (Búciová, 2008) and Anna Remišová (Remišová, 2011) is the opposite, as it includes ethical, economical and legal responsibility into the corporate social responsibility. 
- L. Kuldová (Kuldová, 2010) distinguishes three components within the corporate social responsibility: social, environmental and economic.

In (Schwartz and Caroll, 2003) it is stated that "Carroll's four categories or domains of CSR have been utilized by numerous theorists (Wartick and Cochran 1985; Wood, 1991; Swanson, 1995; Swanson, 1999) and empirical researchers (Aupperle, 1984; Aupperle, Carroll and Hatfield 1985; Burton and Hegarty 1999; Clarkson, 1995; Ibrahim and Angelidis, 1993; Ibrahim and Angelidis, 1994; Ibrahim and Angelidis, 1995; Mallott, 1993; O'Neill, Saunders and McCarthy, 1989; Pinkston and Carroll, 1996; Smith, Wokutch, Harrington and Dennis, 2001; Spencer and Butler, 1987; Strong and Meyer, 1992). Several business and society and business ethics texts have incorporated Carroll's CSR domains (Boatright, 1993; Buchholz 1995; Weiss, 1994) or have depicted the CSR Pyramid (Carroll and Buchholtz, 2000; Carroll and Buchholtz, 2003; Jackson, Miller and Miller, 1997; Sexty, 1995; Trevino and Nelson, 1995)".

Alexander Dahlsrud (Dahlsrud, 2008) in his paper "How Corporate Social Responsibility is defined: an Analysis of 37 definitions" specified five primary areas of CSR, namely: environmental, social, economic, stakeholder and voluntariness (Table 1). He found that four of these five areas appear in $80 \%$ of the definitions and at least three of the five areas are in $97 \%$ of the definitions. Despite the fact that many authors (Table 2) are inclined to the categorization into three areas (like Elkington, 1994), authors inclined to approach of Dahlsrud (Dahlsrud, 2008). The reason for this choice is also the fact (Jankalová, 2016; Jankal and Jankalová, 2016) that companies that wish to successfully develop their activities are forced to engage all key partners into the corporate social responsibility (stakeholder), including all links of the production process, item of providing quality products and services, transparent company management (economic), care of employees (social), environmental protection (environmental) and cooperation with the local community (voluntariness).

Table 1. The five dimensions, how the coding scheme was applied and example phrases

\begin{tabular}{|l|l|l|}
\hline \multicolumn{1}{|c|}{ CSR dimensions } & \multicolumn{1}{|c|}{$\begin{array}{c}\text { The definition is coded to the item if it } \\
\text { refers to }\end{array}$} & \multicolumn{1}{c|}{ Example phrases } \\
\hline environmental & the natural environment & $\begin{array}{l}\text { "a cleaner environment" } \\
\text { "environmental stewardship" } \\
\text { "environmental concerns in business operations" }\end{array}$ \\
\hline social & $\begin{array}{l}\text { "contribute to a better society" } \\
\text { "integrate social concerns in their business operations" } \\
\text { "consider the full scope of their impact on } \\
\text { communities" }\end{array}$ \\
\hline economic & $\begin{array}{l}\text { socio-economic or financial aspects, } \\
\text { including describing CSR in terms of a } \\
\text { business operation }\end{array}$ & $\begin{array}{l}\text { "contribute to economic development" } \\
\text { "preserving the profitability" } \\
\text { "business operations" }\end{array}$ \\
\hline stakeholder & $\begin{array}{l}\text { "interaction with their stakeholders" } \\
\text { "how organisations interact with their employees, } \\
\text { suppliers, customers and communities" } \\
\text { "treating the stakeholders of the firm" }\end{array}$ \\
\hline voluntariness & actions not prescribed by law & $\begin{array}{l}\text { "based on ethical values" } \\
\text { "beyond legal obligations" } \\
\text { "voluntary" }\end{array}$ \\
\hline
\end{tabular}


Table 2. CSR items in the literature

\begin{tabular}{|l|l|}
\hline \multicolumn{1}{|c|}{ Approach } & \multicolumn{1}{c|}{ CSR items } \\
\hline Committee for Economic Development (1971) & inner circle, intermediate circle, outer circle \\
\hline Archie B. Carroll (1979) & economic, legal, ethical, discretionary \\
\hline Archie B. Carroll (1991) & economic, legal, ethical, philanthropic \\
\hline J. Elkington (1994) & economic, social, environmental \\
\hline P. Kotler, N. Lee (2005) & $\begin{array}{l}\text { corporate cause promotions, cause-related marketing, corporate } \\
\text { social marketing, corporate philanthropy, employee volunteering, } \\
\text { socially responsible business practices }\end{array}$ \\
\hline J. Trnková (2005) & economic, social, environmental \\
\hline $\begin{array}{l}\text { Researchers from the Ashridge Business School in } \\
\text { Danish Commerce and Companies Agency (2005) }\end{array}$ & $\begin{array}{l}\text { leadership, vision and values; marketplace activities; workforce } \\
\text { activities; supply chain activities; stakeholder engagement; } \\
\text { community activities; environmental activities }\end{array}$ \\
\hline $\begin{array}{l}\text { M. Prskavcová, K. Marš́́ková, P. Řehořová, } \\
\text { M. Zbránková (2008) }\end{array}$ & \begin{tabular}{l} 
economic, social, environmental \\
\hline A. Dahlsrud (2008)
\end{tabular} \\
\hline G. Mutz (2008) & economic, social, environmental, stakeholder, voluntariness \\
\hline Z. Búciová (2008) & economic, social, environmental \\
\hline N. Lakin, V. Scheubel (2010) & economic, ethical, legal \\
\hline L. Kuldová (2010) & economic, social, environmental \\
\hline A. Remišová (2011) & economic, social, environmental \\
\hline
\end{tabular}

Source: prepared by paper authors, based on Committee for Economic Development, 1971; Carroll, 1979; Carroll, 1991; Elkington, 1994;

Danish Commerce and Companies Agency, 2005; Kotler and Lee, 2005; Trnková, 2005; Búciová, 2008; Dahlsrud, 2008; Mutz, 2008; Prskavcová, Maršíková, Řehořová and Zbránková, 2008; Kuldová, 2010; Lakin and Scheubel, 2010; Remišová, 2011

The problem of the last period becomes the assessment of individual areas of Corporate Social Responsibility, which is associated with a number of CSR approaches (Business Excellence models, sustainability indexes, standards, initiatives) and with their "ability" to measure achieved level in every CSR item (from the perspective of the authors in the environmental, social, economic, stakeholder and voluntariness item). The aim of this study is, based on a comparative analysis, to identify appropriate approach to assessing the achieved level of Corporate Social Responsibility in the areas mentioned above.

The study is organized as follows: section 2 describes the theoretical background (studies) of approaches to evaluating the CSR; section 3 review the findings about primary and secondary data on structure, purpose and application of approaches to evaluating the CSR; section 4 discusses the appropriate approach to evaluating the CSR activities of the company in the light of any previous research; section 5 are conclusions and discuss the issues and future research opportunities of the study.

\section{Theoretical background}

\subsection{Business Excellence models}

"The fact that the excellence models give a comprehensive definition of the meaning of quality management has stimulated the use of these models not only for applying for an award, but for internal self-assessments to monitor and guide the organization in its quality management implementation" (Kok, Wiele, McKenna and Brown, 2001). The two excellence models which have been studied in relation to the social responsibility are The EFQM Excellence Model and The Malcolm Baldrige Model for Performance Excellence.

Although The EFQM Excellence Model is used as the basis of the EFQM Award, from 2004 is also used as "Framework for Corporate Social Responsibility". This framework drew together the expertise from a number of leading companies, as well as including the then recently formed United Nations Global Compact. Since then, the 
knowledge and understanding of topics like "Corporate Social Responsibility" and "Sustainability" have progressed significantly. The new EFQM Framework for Sustainability follows The EFQM Excellence Model 2013. The assessment framework is non-prescriptive and can be used in any organization, regardless of size or sector (EFQM, 2015a).

The EFQM Excellence Model was the first model, which explicitly showed that social responsibility is strongly related to the quality thinking (Kok, Wiele, McKenna and Brown, 2001). Today it is based on 8 fundamental concepts of excellence, and at least one of those concepts has always been linked with corporate social responsibility (value for customers; creating a sustainable future; leading with vision, inspiration and integrity; succeeding through the talent of people; sustaining outstanding results). It was initially called "public responsibility", later "corporate social responsibility". Actually it is called "creating a sustainable future" and characterized as (EFQM, 2015b) "excellent organizations have a positive impact on the world around them by enhancing their performance whilst simultaneously advancing the economic, environmental and social conditions within the communities they touch".

Studies on the CSR concept in The EFQM Excellence Model can be divided into two main sections (Jankal and Jankalová, 2016):

- those that explore the link between the CSR concept and The EFQM Excellence Model as a framework for its evaluation, and

- those that explore the effect of such CSR evaluation on company sustainability performances.

The European Foundation for Quality Management defines CSR in relation with The EFQM Excellence Model as (EFQM, 2004) "a whole range of fundamentals that organizations are expected to acknowledge and to reflect in their actions. It includes among other things respecting human rights, fair treatment of the workforce, customers and suppliers, being good corporate citizens of the communities in which they operate and conservation of natural environment". These fundamentals are seen as not only morally and ethically desirable ends in themselves and as part of the organization's philosophy; but also as key drivers in ensuring that society will allow the organization to survive in the long term, as society benefits from the organization's activities and behavior. This opinion has also Gorenak, who expressed that (Gorenak, 2015) "Using EFQM model, organizations have the support of a performance excellence framework founded on the social responsibility principles to develop sustainable approaches on for business excellence for people, planet, and profit. Each organization has to include social responsibility as part of its strategy, but these approaches have to be measured continuously, and the results have to be reviewed and improved as necessary. EFQM 2013 helps organizations to manage quality successfully and operate according to sustainable determination". In (Margaria, 2004) it is stated that "The EFQM framework for CSR is a new and integrated approach that uses The Excellent Model as a common base. The EFQM has been eager to promote The Excellence model as a tool for effective implementation of CSR". Also Abuhejleh and Yehia (2014) expressed, that "The EFQM Excellence Model Framework for CSR is a fresh and integrated approach that practices The Excellence Model as a mutual foundation".

Other studies (Neergaard and Pedersen, 2003; Porter and Tanner, 2004) argue that the model is based on a stakeholder view of the company and companies can be excellent if they satisfy the needs of their stakeholders stakeholder theory is a common platform for the model as well for much of the literature in CSR. This opinion has also Bucur (2008) and Gorenak (2015). Bucur (Bucur, 2008) considers this model as a very effective management tool that combines CSR with stakeholder engagement in every activity and with many of the performance indicators of the organization. It focuses not only on direct results, but also on the causes and how to get there. Additionally, organizations can easily integrate their existing standards into the EFQM Framework for CSR (for example ISO 9000, ISO 14000 etc.), since it is a management framework, not a standard. Gorenak expressed that (Gorenak, 2015) "The basic concepts of this model are extensive and involve results orientation. Customers are 
one of the main stakeholders; their satisfaction and loyalty are important for each organization. Leadership plays the crucial role; it must be the model as well as the motivator and strategic processes, which are focused on quality, stakeholder partnerships, and sustainability. Employees are one of the main stakeholders, and their involvement reflects as their contribution to innovativeness, improvement, and competitiveness. Stakeholder partnership is a long-term process and is part of the holistic and systemic social responsibility in organizations". In (Abuhejleh and Yehia, 2014) it is stated that "The EFQM CSR Toolbox provides complete and compatible formats for CSR self-assessment, evaluation, and reporting that can be used by any organization. Undertaking this process gives an organization the opportunity to take a step back from its daily operations and assess its overall CSR performance in the form of a series of strengths and areas for improvement, and through a means of comparison to other organizations". A critical review is presented in (Jankalová and Jankal, 2016) who found that "The CSR concept can be found in The EFQM Excellence Model, but it lacks activities especially in the environmental and voluntariness items", and in (Kok, Wiele, McKenna and Brown, 2001) who argued that "ethics and social responsibility are not incorporated in the excellence model which have been developed the European Quality Award. The EFQM Excellence Model's criteria are focused on the needs of all stakeholders, however, only as far as there is a direct relation with the economic responsibility of the organization. The model does not stimulate or demand a position that is more in line with change ethics and proactive change in relation to social responsibility".

About The Malcolm Baldrige Model for Performance Excellence, similar to The EFQM Excellence Model, may be considered as a framework for evaluating the CSR activities of the company. Corporate social responsibility has been an element of the Malcolm Baldrige Criteria for Performance Excellence since 1988. In the initial 1988 Criteria (like Foote, Gaffney and Evans, 2010) "public responsibility was focused narrowly on mechanisms used for external communication of information concerning corporate support of quality assurance or improvement activities outside the company. Over the next several years, this item was expanded to include how the company extended its quality leadership to the external community and integrated its responsibilities to the public for health, safety, environmental protection, and ethical business practice into its quality policies and activities". A significant revision was made to this core value in 2000 (American Society for Quality, 2000): "An organization's leadership should stress its responsibilities to the public and needs to practice good citizenship. These responsibilities refer to basic expectations of your organization related to business ethics and protection of public health, safety, and the environment". In 2003 the core value was re-named "Social Responsibility" although the content remained essentially unchanged (American Society for Quality, 2003). Today, three of 11 core values and concepts are very closely tied to CSR principles (NIST, 2015):

- Societal responsibility (by health care "societal responsibility and community health"): Leaders should stress responsibilities to the public, ethical behavior, and the need to consider societal well-being and benefit, which refers to leadership in and support - within the limits of an organization's resources - of the environmental, social, and economic systems in the organization's sphere of influence.

- Ethics and transparency: Ethical behavior and transparency build trust in the organization and a belief in its fairness and integrity that is valued by all key stakeholders. Organization should stress ethical behavior in all stakeholder transactions and interactions. Transparency is characterized by consistently candid and open communication on the part of leadership and management and by the sharing of clear and accurate information.

- Delivering value and results: By delivering value to key stakeholders, organization builds loyalty, contributes to growing the economy, and contributes to society. Results should be used to deliver and balance value for organization's key stakeholders - students, customers, workforce, stockholders, suppliers, and partners; the public; and the community. Thus results need to be a composite of measures that include not just financial results, but also educational program and service results, process results; student, other customer, and workforce satisfaction and engagement results; and leadership, strategy, and societal performance. 
Craddock (2013) expressed that "The Malcolm Baldrige Criteria for Performance Excellence defined sustainability as your organization's ability to address current business needs and to have the agility and strategic management to prepare successfully for your future business, market, and operating environment. Further expanded the sustainability considerations to include "workforce capability and capacity, resource availability, technology, knowledge, core competencies, work systems, facilities, and equipment. The environmental and societal responsibilities are included as part of the overall leadership governance and societal responsibilities. In other words, sustainability is infused throughout the criteria". Leonard and McAdam stated that (Leonard and McAdam, 2003) "One of the best examples of quality frameworks that incorporate core elements of CSR is the Malcolm Baldrige Criteria for Performance Excellence". Similarly, Fibuch and Van Way observed that the Baldrige Health Care Criteria for Performance Excellence (Fibuch and Van Way, 2012) "provided a clear model for organizational sustainability".

A critical review is presented in (Jankalová and Jankal, 2016) who found that "The CSR concept can be found in The Malcolm Baldrige Model for Performance Excellence, but it lacks activities especially in the environmental and voluntariness items", and in (Kok, Wiele, McKenna and Brown, 2001) who argued that "ethics and social responsibility are not incorporated in the excellence model which have been developed for the Malcolm Baldrige National Quality Award (MBNQA). The MBNQA criteria are mainly related to transaction ethics, where in a very restricted way also the customer needs are taken into account. The model does not stimulate or demand a position that is more in line with change ethics and proactive change in relation to social responsibility".

\subsection{Sustainable indexes}

Jankalová stated that (Jankalová, 2016), "existing independent agencies (Dow Jones from Switzerland, Ethibel from Belgium, FTSE from UK, Business in the Community from UK, James Ethics Centre from Australia, ECPI from Belgium, EIRIS from UK, OEKOM Research AG from Germany), which deal with the rating of corporate social responsibility. Their contribution is in the creation of own indexes with which they measure the performance of companies that behave responsibly towards society. A decision which companies may be included in these indexes depends on the fulfillment of the criteria of "socially responsible behavior" that is setting individually by the agencies. Between the major international indexes belong Dow Jones Sustainability Index, FTSE4Good Index, Ethibel Index, Global Challenges Index and MSCI World ESG Index. In recent years, increased in importance also indexes applied only at regional level. Examples are DAXglobal Sarasin Sustainability Germany Index EUR, Global Challenges Index, STOXX Global ESG Leaders, STOXX Sustainability Indices, Dax Global Alternative Energy Index, Stoxx Europe Christian Index and Hang Seng Corporate Sustainability Index".

Studies on sustainable indexes can be divided into three sections (Jankalová, 2016):

- those that explore the structure of sustainability indexes (Sjöström, 2004; Holt, Kido, Kolind, Mitchell, Song and Swartz, 2004; Hamner, 2005; Kašparová, 2006; ...),

- those that explore the purpose of sustainable indexes (Sjöström, 2004; Beurden and Gössling, 2008; Cerin and Dobers, $2008 ; \ldots$ ) and

- those that explore other dimension, such as their application by the evaluation of Corporate Social Responsibility activities of companies (Avlonas, 2004; Jankalová, 2013; ...).

A combination of the first two approaches is research of E. Sjöström (2004), in which he identified thirteen companies providing sustainability indexes for European, American, Asian, and/or Global markets. It was showed that (Sjöström, 2004) all indexes also do an evaluation of the financial robustness of the companies, because there wouldn't be much of a point of these indexes if there was a financial trade-off. No investor would sacrifice financial pay-off even if it was for a "good cause", because their one and only mission is to maximize the return 
on the investment. The different providers draw the index constituents from varying investment universes: Some use "conventional" indexes, such as Standard and Poor's Global index or Dow Jones World Index. Most sustainability indexes are market capitalization weighted, which means that each stock's weight in the index is proportionate to that stock's total market value. Many indexes have a fixed number of constituents, so if one company is excluded it is immediately replaced with another. The number of constituents in the identified indexes varies from 45 to 2,343. The indexes are normally reviewed every three or four months to ensure that the index composition accurately represents leading sustainability companies, and some are also monitored daily for environmental, economic and social crisis situations that may lead to exclusion from the index. The major underlying purpose behind the sustainability indexes is to measure the performance of companies that meet certain sustainability criteria, and to provide investors with an SRI benchmark (Sustainable Responsibility Investment). In other words, they want to facilitate socially and environmentally responsible investments. Some index providers have a more extensive purpose, in that they also want to increase awareness about CSR and SRI and encourage socially and environmentally responsible behavior, and one could suspect that they are not only profit-driven but also values-driven in their pursuit.

Hamner (Hamner, 2005) examined and analyzed the structure of 12 indexes (Dow Jones Sustainability Index, Ethibel Global Index, Ethical Global Index, FTSE4GOOD Global 100 Index, Humanix 200 Global, ASPI Eurozone Index, Ethinvest Environmental Index Australia, Jantzi Social Index Canada, Johannesburg Stock Exchange / FTSE 4Good Index South Africa, Humanix 50 Index Sweden, Calvert CALVIN Social Index USA, KLD Domini 400 Index USA) with the aim to find the core sustainability criteria used by the 12 indexes and to count the criteria by conceptual groups. The results are in Table 3 and it shows the most popular criteria used by the analyzed indexes.

Table 3. Frequency analysis of criteria in indexes of sustainable corporations

\begin{tabular}{|c|c|c|c|}
\hline Frequency & Sustainability criteria & Frequency & Sustainability criteria \\
\hline $9 x=75 \%$ & Health and safety & $4 x=33 \%$ & $\begin{array}{l}\text { Communication } \\
\text { Discrimination } \\
\text { Legal compliance } \\
\end{array}$ \\
\hline $8 x=67 \%$ & $\begin{array}{l}\text { Corporate governance } \\
\text { CSR performance reporting } \\
\text { Labor and union relations } \\
\text { Pollution prevention }\end{array}$ & $3 \mathrm{x}=25 \%$ & $\begin{array}{l}\text { Contracts } \\
\text { Codes of ethics } \\
\text { Animal relations } \\
\text { Risk management } \\
\text { Environmental performance } \\
\text { Relations to customers and suppliers } \\
\text { Energy sources }\end{array}$ \\
\hline $6 x=50 \%$ & $\begin{array}{l}\text { Training and education } \\
\text { Quality } \\
\text { Compensation } \\
\text { Diversity }\end{array}$ & $2 \mathrm{x}=17 \%$ & $\begin{array}{l}\text { Leadership and incentives } \\
\text { Management } \\
\text { Non-executive director remuneration } \\
\text { Conduct of business } \\
\text { Sustainability assessment } \\
\text { Rights Management } \\
\text { Profit sharing } \\
\text { Family support } \\
\text { Product safety } \\
\text { Recycling } \\
\text { Environmental management system }\end{array}$ \\
\hline $5 x=42 \%$ & $\begin{array}{l}\text { Innovation } \\
\text { Benefits } \\
\text { Human rights }\end{array}$ & & \\
\hline
\end{tabular}

Source: Hamner, 2005 
This research provides (Hamner, 2005), that the most significant observation is the strong focus on internal employee relations for sustainability, such as health and safety, labor relations and pollution prevention. Hamner's point of view, investors understand that good performance is created by a good business culture and sustainability programs should focus on internal development first and external efforts second. It was also being noted that three of the dominant criteria are often integrated: training and education leads to pollution prevention which improves health and safety. Hamner's research confirmed earlier realized research (Holt, Kido, Kolind, Mitchell, Song and Swartz, 2004), who analyzed indexes DJSI, Ethibel, FTSE4Good, Domini400 and Calvert. By the comparison of monitoring areas, he came to the conclusion that the monitored area of the individual indexes differed evidently. On the discrepancy of indexes also pointed Kašparová (2006), her research was based on extensive research of Hamner (2005).

The second section on studies focuses on the purpose of sustainable indexes, which explore the link between sustainable indexes and areas as Corporate Social Performance (CSP) and Sustainable Responsibility Investment (SRI). Beurden and Gössling (2008), also in line with Sotorrio and Sanchez (2008), describe CSP as a concept of three categories (Comincioli, Poddi andVergalli, 2012):

- CSP1: social disclosure about social concern (Orlitzky, Schmidt and Rynes, 2003; Wu, 2006),

- CSP2: corporate action, such as philanthropy, social programs and pollution control,

- CSP3: corporate reputation ratings or social indices that may be provided by social rating institutions, such as KLD, EIRIS, Fortune, Moskowitz or ad hoc indices drawn up by the researchers themselves (Beliveau, Cottrill and O'Neill, 1994; Brammer and Pavelin, 2006; Hillman and Keim, 2001; Johnson and Greening, 1999; Mahoney andThorne, 2005; Moore, 2001).

Cerin and Dobers (2008) in their study "The contribution of sustainable investments to sustainable development mentioned" (Cerin and Dobers, 2008): In the last decade there has been a surge of new sustainable investment mutual funds and indices (SiRi Company, 2004; Sjöström, 2004). This has spurred critical research on their compositions, including ratings (Koellner, Weber, Fenchel and Scholz, 2005; SustainAbility, 2004; Figge, Schaltegger, 2000). Cerin and Dobers (2001a) found that other factors than sustainability (e.g. market capital size and back casting methodology) explained the Dow Jones Sustainability Group Index (DJSGI) out performance of Dow Jones Global Index (DJGI). The likely reason is the fact that DJSGI has selected its components mainly on the basis of information from the companies themselves (Cerin, Dobers, 2001b). Illnitch, Soderstrom and Thomas (1998) evaluated environmental ratings and found them to rely on public reactions rather than on precise and measurable outcomes. Instead the subjectivity in their formulations may raise a dangerous circularity where the rankings are based on reputation and the reputation is partly based on the ranking. Hawken and the Natural Capital Institute (2004) have, moreover, detected that almost identical constituents have been chosen (as of Oct. 2003) in the combined portfolio holdings of American SI mutual funds as of the 30 largest market capitalization size firms composing the Dow Jones Industrial Average. Some researchers (Cerin and Dobers, 2001a; Louche, 2004), however, also conclude that sustainability indices have indeed contributed to making sustainable investments a viable commercial project and transformed sustainable investments to an element of the broader Corporate Social Responsibility field.

The last groups are studies dealing with the application of the sustainability indexes by the evaluation of Corporate Social Responsibility activities of companies (Avlonas, 2004; Jankalová, 2013; Jankalová, 2016). It is especially this research field that indexes are the tools of reporting, self-assessment and assessment of CSR activities of companies (Table 4). 
Table 4. Research on CSR models, standards, guidelines and indexes

\begin{tabular}{|l|l|l|l|}
\hline \multicolumn{1}{|c|}{ CSR approach } & \multicolumn{1}{c|}{ Tool for reporting } & Tool for self-assessment & Tool for assessment \\
\hline The EFQM Excellence Model & ++ & +++ & +++ \\
\hline Social Accountability - SA 8000 & + & + & +++ \\
\hline ISO 14OOO & & ++ & +++ \\
\hline EMAS & + & ++ & +++ \\
\hline AccountAbility 1000 (AA1000) & ++ & + & +++ \\
\hline Global Reporting Initiative (GRI) & +++ & ++ & \\
\hline Value Management System (VMS) & & ++ & ++ \\
\hline Dow Jones Sustainability Index & + & ++ & \\
\hline FTSE4good & & ++ & \\
\hline
\end{tabular}

Source: a comparison by Avlonas, 2004

\section{Interpretation of the approaches analysis 3.1. Business Excellence models}

The EFQM Excellence Model includes CSR in various forms in all examined items (Leadership; Strategy; People; Partnerships and Resources; Processes, Products and Services; Results). The EFQM Framework for CSR provides guidelines (EFQM, 2004) "on how to identify, improve and integrate the social, environmental and economic impacts of its operations into policy and strategy and the day-to-day management of an organization, taking all stakeholders into account". The model is divided into the same nine criteria as The EFQM Excellence Model. Five of these are "Enablers" and four are "Results". A separate criterion for measuring the organization's impact on the society is the criterion 8 "Society Results", according to which (EFQM, 2013) "excellent organizations achieve and sustain outstanding results that meet or exceed the needs and expectations of relevant stakeholders within society". The weight of sub-criteria is shifted with regard to perception and internal indicators. The sub-criterion 8a Measurement of Perception has the weight of 25\% and the sub-criterion 8b Performance Indicators has $75 \%$. This indicator with the weight of $10 \%$ within the whole model indicates the rate of corporate social responsibility, level of its influence over the environment and its benefits and significance for the society.

The measurement of CSR activities of the enterprise according to criteria of The EFQM Excellence Model is significantly exact. The rate of meeting sub-criteria of assumptions and sub-criteria of results is assessed within individual criteria in the range from 0 to $100 \%$ on the grounds of the RADAR principle. Together with this scoring methodology are the organizations able to identify the strengths and the items where they need to focus on improvement.

The criteria for Performance Excellence in The Malcolm Baldrige Model for Performance Excellence include CSR in various forms (NIST, 2015), mostly in the categories Leadership and Results (Senior Leadership, Governance and Societal Responsibilities, Customer-Focused Results, Leadership and Governance Results). The CSR concept is in other criteria linked within their individual items (Jankalová and Jankal, 2016). Already (Jankalová and Jankal, 2016) when creating the Organizational Profile, some supporting questions are aimed at the CSR item, such as in the part Organizational Relationships - Customers and Stakeholders: "What are your key market segments, customer groups, and stakeholder groups, as appropriate?, in the part Strategic Context: What are your key strategic challenges and advantages in the areas of business, operations, societal responsibilities, and workforce?" Between strategic advantages (mentioned in the part Organizational Situation) are listed also (NIST 2015): Environmental ("green") stewardship and Social responsibility and community involvement.

The measurement of CSR activities of the enterprise according to criteria of The Malcolm Baldrige Model for Performance Excellence is also significantly exact. The scoring of responses to items is based on two evaluation dimensions: Process and Results, in the range from 0 to $100 \%$. The four factors used to evaluate process are Approach, Deployment, Learning and Integration (ADLI). The four factors used to evaluate results are Levels, 
Trends, Comparisons and Integration (LTCI). Together with this scoring methodology are the organizations able to identify the strengths and the areas where they need to focus on improvement.

Jankalová and Jankal in (Jankalová and Jankal, 2016) identified the proximity rate of the CSR concept in two models, namely The EFQM Excellence Model and The Malcolm Baldrige Model for Performance Excellence, as they belong to frequently used approaches in the practice. The calculation of the proximity rate of the CSR concept in the analyzed models depends on the number of sub-criteria or criteria of the model, in which the i-th CSR item appears. The determination of the proximity rate was preceded by:

- determination of sub-criteria in the analyzed models in the i-th CSR item appears,

- determination of the number of criteria of the model in the i-th CSR item appears $\left(\mathrm{N}_{c} \mathrm{CSR}_{\mathrm{i}}\right)$,

- calculation of the model CSR criterion score $\left({ }_{m} \mathrm{CSR}_{\mathrm{ics}}\right)$.

The results of these findings are stated in the Table 5, where $\mathrm{N}_{c} \mathrm{CSR}_{\mathrm{i}}=$ number of criteria of the model in the i-th CSR item appears; $\mathrm{N}_{\mathrm{mc}}=$ number of all criteria of the analyzed model; $\mathrm{m}_{\mathrm{CSR}} \mathrm{ics}_{\mathrm{ic}}=$ model $\mathrm{CSR}$ criterion score; $\mathrm{NR}_{\mathrm{m}} \mathrm{CSR}_{\mathrm{ics}}=$ proximity rate of the CSR concept in criteria of the respective model.

Table 5. The proximity rate of the CSR concept in criteria of the respective model

\begin{tabular}{|l|l|l|l|l|}
\hline \multicolumn{1}{|c|}{ CSR item } & \multicolumn{1}{|c|}{$\begin{array}{c}\text { The EFQM Excellence Model } \\
\mathbf{N}_{\mathrm{mc}}=9\end{array}$} & \multicolumn{2}{c|}{$\begin{array}{c}\text { The Malcolm Baldrige Model } \\
\mathbf{N}_{\mathrm{mc}}=7\end{array}$} \\
\hline & $\mathbf{N}_{\mathbf{c}} \mathbf{C S R}_{\mathbf{i}}$ & $\mathbf{m C S R}_{\mathbf{i c s}}$ & $\mathbf{N}_{\mathbf{c}} \mathbf{C S R}_{\mathbf{i}}$ & $\mathbf{m}_{\mathbf{C}}$ \\
\hline environmental & 5 & $55,56 \%$ & 4 & $57,14 \%$ \\
\hline social & 6 & $66,67 \%$ & 6 & $85,71 \%$ \\
\hline economic & 9 & $100,00 \%$ & 5 & $71,43 \%$ \\
\hline stakeholder & 7 & $77,78 \%$ & 7 & $100,00 \%$ \\
\hline voluntariness & 4 & $44,44 \%$ & 5 & $71,43 \%$ \\
\hline${ }_{\mathrm{n}} \mathrm{CSR}_{\mathrm{i}}=5$ & $\mathrm{NR}_{\mathrm{m}} \mathrm{CSR}_{\mathrm{ics}}=68,89 \%$ & $\mathrm{NR}_{\mathrm{m}} \mathrm{CSR}_{\mathrm{ics}}=77,14 \%$ \\
\hline
\end{tabular}

Source: Jankalová and Jankal, 2016

The main conclusions of the study of Jankalová and Jankal (2016) are (Jankalová and Jankal, 2016):

- the CSR concept can be found in each of the analyzed models, the difference is in the determined proximity rate of the concept in those models,

- the shortcoming of the analyzed models is the uneven representation of individual CSR items in sub-criteria - the calculated weightings of the five CSR components in The EFQM Excellence Model were (after recalculation): environmental $=1,20$; social $=2,00$; economic $=2,60$; stakeholder $=3,00$; voluntariness $=$ 1,20; the weightings of the five CSR components in The Malcolm Baldrige Model for Performance Excellence were (after recalculation): environmental $=1,35$; social $=2,40$; economic $=2,20$; stakeholder $=$ 2,70 ; voluntariness $=1,35$,

- the analyzed models lack the list of activities within individual CSR items,

- the analyzed models lack activities especially in the environmental and voluntariness items.

\subsection{Sustainable indexes}

The problem of the indexes (Jankalová, 2013) is the objectivity of the data collected, since the source of them are personal interviews, websites, annual reports, reports on sustainable development and proper environmental protection of analyzed companies. Despite verification by the independent auditor, these reports often show signs of subjectivity due mainly mutual incomparability of data. Another problem is transparency in the evaluation of corporate social responsibility provided by rating agencies, since these agencies often use a methodology which is not disclose, because it is their know-how. Some rating agencies published indexes that assess only the company's 
reputation. In this case, the starting point is stakeholders' views on the company obtained especially by questionnaire survey. The problem in this case is known favoring of large companies, as these communicate with the public more often than small, of which beneficial activities know often only closed group of people. Mentioned indexes are also the basis for sustainable investments. The problem is that, since individual indexes are different in analyzed areas and also in indicators in the various areas and scales defined for each area, it is very difficult to compare these indexes.

Incomparability of indexes also causes (Jankalová, 2016):

- The various definitions of corporate social responsibility that ambiguously identify the desired behavior of the business entity. While in overseas countries, we can talk more about corporate philanthropy (for many companies is that donations to foundations and support non-profit projects) in Europe CSR reflected in integration of principle areas of corporate social responsibility into the business strategy of the company.

- Different views on the identification of the areas of corporate social responsibility, what is proven by statements of domestic and foreign authors as A. B. Caroll, N. Lakin, V. Scheubel, G. Mutz, Z. Búciová, A. Dahlsrud, A. Remišová, L. Kuldová, J. Trnková, M. Prskavcová.

- Various purposes of sustainable indexes.

\section{Identification of the appropriate approach to evaluating the CSR activities of the company}

Research problem of this study is the identification of the appropriate approach to evaluating the CSR activities of the company in five areas of CSR, namely: environmental, social, economic, stakeholder and voluntariness. The identification of the appropriate approach is presented as multi-criteria analysis. The approach of Jankalová and Jankal (Jankalová and Jankal, 2016) for the calculation of the model CSR criterion score was used also for sustainable indexes (namely FTSE ESG and RobecoSAM). The selection of sustainable indexes was determined by the availability of the structure used by the evaluation. Five areas of CSR are used as the criteria with the equal importance. The evaluation matrix is in the Table 6.

Table 6. The evaluation matrix

\begin{tabular}{|l|l|l|l|l|}
\hline & \multicolumn{1}{|c|}{$\begin{array}{c}\text { The EFQM } \\
\text { Excellence Model }\end{array}$} & $\begin{array}{c}\text { The Malcolm } \\
\text { Baldrige Model }\end{array}$ & \multicolumn{1}{|c|}{ FTSE ESG } & RobecoSAM \\
\hline environmental & $55,56 \%$ & $57,14 \%$ & $35,71 \%$ & $25,71 \%$ \\
\hline social & $66,67 \%$ & $85,71 \%$ & $35,71 \%$ & $34,28 \%$ \\
\hline economic & $100,00 \%$ & $71,43 \%$ & $28,57 \%$ & $40,00 \%$ \\
\hline stakeholder & $77,78 \%$ & $100,00 \%$ & $64,28 \%$ & $25,71 \%$ \\
\hline voluntariness & $44,44 \%$ & $71,43 \%$ & $28,57 \%$ & $20,00 \%$ \\
\hline
\end{tabular}

Source: authors, based on Jankalová and Jankal, 2016

At the next stage, all evaluation values from the Table 6 are normalized and the new normalized decision matrix is in the Table 7. 
Table 7. The normalized decision matrix

\begin{tabular}{|l|l|l|l|l|}
\hline \multicolumn{1}{|c|}{ Variant } & $\begin{array}{c}\text { The EFQM } \\
\text { Excellence Model }\end{array}$ & $\begin{array}{c}\text { The Malcolm } \\
\text { Baldrige Model }\end{array}$ & FTSE ESG & RobecoSAM \\
\hline environmental & 0,97 & 1,00 & 0,62 & 0,45 \\
\hline social & 0,78 & 1,00 & 0,42 & 0,40 \\
\hline economic & 1,00 & 0,71 & 0,29 & 0,40 \\
\hline stakeholder & 0,78 & 1,00 & 0,64 & 0,26 \\
\hline voluntariness & 0,62 & 1,00 & 0,40 & 0,28 \\
\hline
\end{tabular}

Source: authors

Finally, according the results from Table 7 the variants' ranking is ordered and the best ranked variant is proposed as a solution (Table 8). In case that the criteria have different importance, it is necessary to make conversion of normalized values to the weighted values.

Table 8. The final score and ranking

\begin{tabular}{|l|l|l|}
\hline \multicolumn{1}{|c|}{ Variant } & \multicolumn{1}{c|}{ Score } & Ranking \\
\hline The Malcolm Baldrige Model & 4,71 & 1 \\
\hline The EFQM Excellence Model & 4,15 & 2 \\
\hline FTSE ESG & 2,37 & 3 \\
\hline RobecoSAM & 1,79 & 4 \\
\hline
\end{tabular}

Source: authors

From the Table 8 follows that the best approach for evaluating the CSR activities of the company may be considered The Malcolm Baldrige Model for Performance Excellence.

\section{Conclusions}

Praxis is proof of the fact that there are currently methods, norms and initiatives that enable evaluation of the CSR activities of the company. As the framework can be used Business Excellence models, sustainability indexes, standards and initiatives.

Business Excellence models, as the models with fixed scale of criteria, has recently, with the increase of importance of corporate social responsibility, also became the framework for evaluating the CSR activities of the company. Between the best known models belong The EFQM Excellence Model in Europe and The Malcolm Baldrige Model for Performance Excellence in the USA. According to the own multi-criteria analysis, The Malcolm Baldrige Model for Performance Excellence is more suitable framework for evaluating the CSR activities of the company, as The EFQM Excellence Model, or sustainability indexes (namely FTSE ESG and RobecoSAM).

Despite the number and variety of approaches to the evaluation of CSR activities of the company authors of this study recommends companies to evaluate their own activities based on their selected approach. The question is "Which one?". By the approach of Avlonas (Avlonas, 2004) important is also the purpose of the evaluation of CSR activities of the company - Tool for reporting, Tool for self-assessment or Tool for assessment?

According to the aim of the study, decisive was the approach that is suitable as the tool for self-assessment and tool for assessment too. Approach which would only serve as a tool for reporting would cover only part of the CSR and we could not talk about the complex approach for evaluating the CSR activities of the company. For company reporting are essential standards as Global Reporting Initiative, World Business for Sustainable 
Development Reporting Project and AA1000 AccountAbility/Assurance Standard. The GRI Sustainability Reporting Guidelines (ISO, 2014) are the most widely used sustainability reporting framework in the world and enable all companies and organizations to report on their economic, environmental, social and governance performance. GRI's mission is to make sustainability reporting standard practice.

Due to changes in the requirements of stakeholders, there is a constant revision of Business Excellence models, sustainability indexes, standards and initiatives, which are suitable for the evaluation and reporting of CSR activities of the company. Therefore, dealing with this issue is important in the future because it is necessary to continuously monitor CSR activities of the company.

The results of the study may represent a starting point for future research, oriented also on the possibilities of application of other Business Excellence Models as the approaches to evaluating the CSR activities of the company.

\section{Acknowledgements}

The study was conducted within the project VEGA 1/0916/15 offered by The Ministry of Education, Science, Research and Sport of the Slovak Republic.

\section{References}

Abuhejleh, A.; Yehia, S. 2014. EFQM Framework for Corporate Social Responsibility in Healthcare Sector, International Journal of Business Quantitative Economics and Applied Management Research 1(7): 46-67.

American Society for Quality. 2000. Criteria for Performance Excellence. Available on the Internet:

https://www.nist.gov/sites/default/files/documents/baldrige/publications/archive/2001_Business_Criteria.pdf

American Society for Quality. 2003. Education Criteria for Performance Excellence. Available on the Internet: https://www.nist.gov/sites/default/files/documents/baldrige/publications/archive/2004_Education_Criteria.pdf

Aupperle, K. E. 1984. An Empirical Measure of Corporate Social Orientation, in Preston, L.E. (Ed.). Research in Corporate Social Performance and Policy. Greenwich, Conn.: JAI Press, 27-54.

Aupperle, K. E.; Carroll, A. B.; Hatfield, J. D. 1985. An Empirical Examination of the Relationship between Corporate Social Responsibility and Profitability, Academy of Management Review 28(2): 446-463.

Avlonas, N. 2004. The EFQM Framework for Corporate Social Responsibility. Available on the Internet: http://www.das-nachhaltige-krankenhaus.at/Dokumente/docs/EFQMCSRFrameworkECOPF.pdf

Baronienè, L.; Žirgutis, V. 2016. Management decisions for sustainable development: medical software case study, Entrepreneurship and Sustainability Issues 4(2): 129-145. DOI: http://dx.doi.org/10.9770/jesi.2016.4.2(2)

Beliveau, B.; Cottrill, M.; O'Neill, H. M. 1994. Predicting corporate social responsiveness: A model drawn from three perspectives, Journal of Business Ethics 13(9): 731-738.

Beurden, V. P.; Gossling, T. 2008. The Worth of Values - A Literature Review on the Relation between Corporate Social and Financial Performance, Journal of Business Ethics 82(2): 407-424.

Boatright, J. R. 1993. Ethics and the Conduct of Business. Englewood Cliffs, N.J.: Prentice Hall.

Brammer, S. J.; Pavelin, S. 2006. Corporate Reputation and Social Performance: The Importance of Fit, Journal of Management Studies 43(3): 435-455. 
The International Journal

ISSN 2345-0282 (online) http://jssidoi.org/jesi/

2017 Volume 4 Number 4 (June)

http://doi.org/10.9770/jesi.2017.4.4(4)

Bucur, M. 2008. Studies and research regarding implementation of CSR in organizations. Proceedings of International Conference on Economics, law and Management 2008 (ICELM-3). Tirgu Mureş, Romania: Petru Maior University. June 4-7, 7 pp. Available on the Internet: http://www.upm.ro/proiecte/EEE/Conferences/papers/S227.pdf

Buchholz, R. A. 1995. Business, Environment, and Public Policy. Englewood Cliffs, N.J.: Prentice Hall.

Burton, B. K.; Hegarty, W. H. 1999. Some Determinants of Student Corporate Social Responsibility Orientation, Business and Society 38(2): 188-205.

Búciová, Z. 2008. K problematike chápania spoločenskej zodpovednosti podnikov [Towards the understanding of corporate social responsibility]. 4th Annual International Bata Conference for Ph.D. Students and Young Researchers. Zlín: Univerzita Tomáše Bati ve Zlíně. April 10, 1-8.

Carroll, A. B. 1979. A three-dimensional conceptual model of corporate social performance, Academy of Management Review 4: 497-505.

Carroll, A. B. 1991. The pyramid of corporate social responsibility: Toward the moral management of organizational stakeholders, Business Horizons 34(4): 39-48.

Carroll, A. B.; Buchholtz, A. K. 2000. Business and Society: Ethics and Stakeholder Management. Cincinnati: South-Western Publishing Co.

Carroll, A. B.; Buchholtz, A. K. 2003. Business and Society: Ethics and Stakeholder Management. Cincinnati: Thomson-South-Western.

Cerin, P.; Dobers, P. 2001a. What does the performance of the Dow Jones Sustainability Group Index tell us?, Eco-Management and Auditing 8(3): 123-133.

Cerin, P.; Dobers, P. 2001b. Who is rating the raters?, Corporate Environmental Strategy 8(2): 95-97.

Cerin, P.; Dobers, P. 2008. The contribution of sustainable investments to sustainable development, Progress in Industrial Ecology - An International Journa, 5(3): 161-179.

Clarkson, M. B. E. 1995. A Stakeholder Framework for Analyzing and Evaluating Corporate Social Performance, Academy of Management Review 20(1): 92-117.

Comincioli, N.; Poddi, L.; Vergalli, S. 2012. Corporate Social Responsibility and Firms' Performance: a Stratigraphical Analysis. Available on the Internet: http://papers.ssrn.com/sol3/papers.cfm?abstract_id=2132202

Committee for Economic Development. 1971. Social responsibilities of business corporations. New York: Committee for Economic Development.

Craddock, W. T. 2013. How Business Excellence Models Contribute to Project Sustainability and Project Success, in Silvius, G.; Tharp, J. (Eds.). Sustainability Integration for Effective Project Management. Hershey, PA: IGI Global.

Dahlsrud, A. 2008. How Corporate Social Responsibility is Defined: an Analysis of 37 Definitions, Corporate Social Responsibility and Environmental Management 15: 1-13.

Danish Commerce and Companies Agency. 2005. Catalogue of CSR Activities: A broad overview. Hertfordshire: Ashridge Centre for Business and Society.

EFQM. 2004. The EFQM Framework for Corporate Social Responsibility. Brussels: EFQM.

EFQM. 2013. EFQM Excellence Model. Brussels. Brussels: EFQM.

EFQM. 2015a. The EFQM Framework for Sustainability. Brussels: EFQM.

EFQM. 2015b. Fundamental Concepts. Brussels: EFQM. 
Elkington, J. 1994. Towards the Sustainable Corporation: Win-Win-Win Business Strategies for Sustainable Development, California Management Review 36(2): 90-100.

Elkington, J. 1997. Cannibals with forks - The triple bottom line of 21st century business. Oxford: Capstone.

Fibuch, E.; Van Way, Ch. 2012. Sustainability: A Fiduciary Responsibility of Senior Leaders?, Physician Executive 38(2): 36-43.

Figge, F.; Schaltegger, S. 2000. Erfolgreich enttäuschend [Successfully disappointing], Politische Ökologie 67-68: 98-100.

Figurska, I. 2014. Sustainable entrepreneurship: localization, acquiring and use of knowledge sources in competitive organization, Entrepreneurship and Sustainability Issues 1(4): 210-222. DOI: http://dx.doi.org/10.9770/jesi.2014.1.4(3)

Foote, J.; Gaffney, N.; Evans, J. R. 2010. Corporate social responsibility: Implications for performance excellence, Total Quality Management \& Business Excellence 21(8): 799-812.

Gjølberg, M. 2009. Measuring the immeasurable? Constructing an index of CSR practices and CSR performance in 20 countries, Scandinavian Journal of Management 25: 10-22.

Gorenak, Š. 2015. European Foundation for Quality Management Excellence Model Can Encourage ISO 26000 Implementation, in Bobek, V. (Ed.). Perspectives on Business and Management. Rijeka, Croatia: InTech.

Grubicka, J.; Matuska, E. 2015. Sustainable entrepreneurship in conditions of UN (Safety) and technological convergence, Entrepreneurship and Sustainability Issues 2(4): 188-197. DOI: http://dx.doi.org/10.9770/jesi.2015.2.4(2)

Hamner, B. 2005. Integrating Market-Based Sustainability Indicators and Performance Management Systems. Seattle, WA: Cleaner Production International.

Hawken, P. 2004. Is Your Money Where Your Heart Is? Socially responsible investing. How the SRI industry has failed to respond to people who want to invest with conscience and what can be done to change it. Available on the Internet: http://www.dragonflymedia.com/portal/featured_stories/200410/hawken_paul.html

Hillman, A. J.; Keim, G. 2001. Shareholder Value, Stakeholder Management, and Social Issues: What's the Bottom Line?, Strategic Management Journal 22(2): 125-139.

Ibrahim, N. A.; Angelidis, J. A. 1993. Corporate Social Responsibility: A Comparative Analysis of Perceptions of Top Executives and Business Students, The Mid-Atlantic Journal of Business 29(3): 303-314.

Ibrahim, N. A.; Angelidis, J. A. 1994. Cross-National Differences in Social Responsiveness: A Study of American and Egyptian Business Students, International Journal of Management 11(3): 815-826.

Ibrahim, N. A.; Angelidis, J. A. 1995. The Corporate Social Responsiveness Orientation of Board Members: Are There Differences Between Inside and Outside Directors?, Journal of Business Ethics 14: 405-410.

Ilinitch, A. Y.; Soderstrom, N. S., E.; Thomas, T. 1998. Measuring corporate environmental performance, Journal of Accounting and Public Policy 17(4-5): 383-408.

ISO. 2014. GRI G4 Guidelines and ISO 26000:2010. How to use the GRI G4 Guidelines and ISO 26000 in conjunction. Available on the Internet: http://www.iso.org/iso/iso-gri-26000_2014-01-28.pdf

Jackson, J. H.; Miller, R. L.; Miller, S. G. 1997. Business and Society Today: Managing Social Issues. Pacific Grove: West Publishing Company.

Jankalová, M. 2013. Spoločensky zodpovedné podnikanie [Corporate Social Responsibility], in Štofková, K., Jankalová, M., Močková, M. (Ed.). Manažment a siet’ové podnikanie [Management and Network's business]. Žilina: EDIS, 61-82.

Jankalová, M. 2016. Approaches to the Evaluation of Corporate Social Responsibility, Procedia Economics and Finance 39: 580-587. 
Jankal, R.; Jankalová, M. 2016. The Application of The EFQM Excellence Model by the Evaluation of Corporate Social Responsibility Activities of Companies, Procedia Economics and Finance 39: 660-667.

Jankalová, M.; Jankal, R. 2016. The proximity rate of the Corporate Social Responsibility concept in the Excellence Models, Quality Access to Success 17(155): 71-83.

Johnson, R. A.; Greening, D. W. 1999. The Effects of Corporate Governance and Institutional Ownership Types on Corporate Social Performance, The Academy of Management Journal 42(5): 564-576.

Kašparová, K. 2006. Společenská zodpovědnost podniku - způsoby jejího měření a vztah k finanční výkonnosti podniku [Corporate social responsibility - its measurement and relationship to the financial performance of the company], Proceedings of Development trends of businesses II. Brno: Masarykova univerzita. 159-217.

Koellner, T.; Weber, O.; Fenchel, M.; Scholz, R. 2005. Principles for sustainability rating of investment funds, Business Strategy and the Environment 14(1): 54-70.

Kok, P.; Wiele, T.; McKenna, R.; Brown. A. 2001. A Corporate Social Responsibility Audit within a Quality Management Framework, Journal of Business Ethics 31: 285-297.

Kotler, P.; Lee, N. 2005. Corporate Social Responsibility. Doing the Most Good for Your Company and Your Cause. Hoboken, New Jersey: John Wiley \& Sons.

Kuldová, L. 2010. Společenská odpovědnost firem [Corporate Social Responsibility]. Plzeň: OPS.

Lakin, N.; Scheubel, V. 2010. Corporate Community Involvement: The Definitive Guide to Maximizing Your Business 'Societal Engagement. Redwood City, CA: Stanford University Press.

Leonard, D.; McAdam, R. 2003. Corporate social responsibility, Quality Progress 36(10): 27-32.

Louche, C. 2004. Ethical Investment: Processes and Mechanisms of institutionalisation in the Netherlands. Unpublished doctoral thesis. Rotterdam: Erasmus University Rotterdam.

Mahoney, L. S.; Thorne, L. 2005. Corporate Social Responsibility and Long-Term Compensation: Evidence from Canada, Journal of Business Ethics 57(3): 241-253.

Mallott, M. J. 1993. Operationalizing Corporate Social Performance: Managerial Perceptions of Principles, Processes and Outcomes. Unpublished doctoral dissertation. Pittsburgh: University of Pittsburgh.

Margaria, P. 2004. CSR in the frame, UK Excellence 3.

Holt, D.; Kido, A.; Kolind, K.; Mitchell, C.; Song, J.; Swartz, R. 2004. Measuring Sustainability. Carolina: Chapel Hill, University of North Carolina, Kenan-Flagler Business School.

Moore, G. 2001. Corporate Social and Financial Performance: An Investigation in the U.K. Supermarket Industry, Journal of Business Ethics 34 (3-4): 299-315.

Mutz, G. 2008. Corporate Social Responsibility (CSR) bei kleinen und mittleren Unternehmen (KMU) in Deutschland. [Corporate Social Responsibility in small and medium-sized enterprises (SMEs) in Germany.] München: Rainer Hampp Verlag.

Neergaard, P.; Pedersen, E. R. 2003. Corporate Social Behaviour: Between the rules of the game and law of the Jungle, Journal of Corporate Citizenship 12: 43-57.

NIST. 2015. 2015-2016 Baldrige Excellence Framework: A Systems Approach to Improving Your Organization's Performance. Gaithersburg, MD: U.S. Department of Commerce, National Institute of Standards and Technology.

O’Neill, H. M.; Saunders, C. B.; McCarthy, A. D. 1989. Board Members, Corporate Social Responsiveness and Profitability: Are Tradeoffs Necessary?, Journal of Business Ethics 8: 353-357. 
Orlitzky, M.; Schmidt, F. L.; Rynes, S. L. 2003. Corporate Social Performance and Firm Risk: A Meta-Analytic Review, Business \& Society 40(4): 369-396.

Pinkston, T. S.; Carroll, A. B. 1996. A Retrospective Examination of CSR Orientations: Have They Changed?, Journal of Business Ethics 15: 199-206.

Porter, L. J.; Tanner, S. J. 2004. Assessing Business Excellence. Oxford: Elsevier Butterworth-Heinemann.

Prskavcová, M.; Maršíková, K.; Řehořová, P.; Zbránková, M. 2008. Společenská odpovědnost firem, lidský kapitál, rovné přiležitosti a environmentální management s využitím zahraničnich zkušenosti [Corporate social responsibility, human capital, equal opportunities and environmental management using international experience]. Liberec: Technická univerzita v Liberci.

Raudeliūnienè, J.; Tvaronavičienè, M.; Dzemyda, I.; Sepehri, M. 2014. Sustainable entrepreneurship through energy stewardship: role of values and behavioral patterns, Entrepreneurship and Sustainability Issues 2(2): 107-117. DOI: http://dx.doi.org/10.9770/jesi.2014.2.2(6)

Remišová, A. 2011. Etika a ekonomika [Ethics and economics]. Bratislava: Kalligram.

Sapkauskiene, A.; Leitoniene, S. 2014. Corporate social responsobility research methods analysis, European Scientific Journal 1: 237-244.

Schwartz, M. S.; Carroll, A. B. 2003. Corporate Social Responsibility: a three-domain approach, Business Ethics Quarterly 13(4): 503530 .

Sexty, R. W. 1995. Canadian Business and Society. Scarborough, Ont.: Prentice Hall.

SiRi Company. 2004. Green, social and ethical funds in Europe 2004. Available on the Internet: http://www.ecodes.org/documentos/archivo/Fondos_Europa_2004.pdf

Sjostrom, E. 2004. Investment Stewardship: Actors and Methods for Socially and Environmentally Responsible Investments. Stockholm: Nordic Partnership in collaboration with the Stockholm School of Economics.

Smith, W. J.; Wokutch, R. E.; Harrington, K. V.; Dennis, B. S. 2001. An Examination of the Influence of Diversity and Stakeholder Role on Corporate Social Orientation, Business and Society 40(3): 266-294.

Sotorrio, L. L.; Sanchez, J. L. F. 2008. Corporate Social Responsibility of the Most Highly Reputed European and North American Firms, Journal of Business Ethics 82(2): 379-390.

Spencer, B. A.; Butler, J. K. Jr. 1987. Measuring the Relative Importance of Social Responsibility Components: A Decision Modeling Approach, Journal of Business Ethics 6: 573-577.

Strong, K. C.; Meyer, G. D. 1992. An Integrative Descriptive Model of Ethical Decision Making, Journal of Business Ethics 11: 89-94.

SustainAbility. 2004. Values for money: Reviewing the Quality of SRI Research. London: SustainAbility.

Swanson, D. L. 1995. Addressing a Theoretical Problem by Reorienting the Corporate Social Performance Model, Academy of Management Review 20(1): 43-64.

Swanson, D. L. 1999. Toward an Integrative Theory of Business and Society: A Research Strategy for Corporate Social Performance, Academy of Management Review 24(3): 521-596.

Trevino, L. K.; Nelson, K. A. 1995. Managing Business Ethics. New York: John Wiley and Sons.

Trnková, J. 2005. Co znamená společenská odpovědnost firem? [What does it mean corporate social responsibility?], in Kolektiv autorů (Ed.). Např́č společenskou odpovědností firem [Across Corporate Social Responsibility]. Kladno: AISIS, 30-34.

Tvaronavičienè, M. 2014. If industrial sector development is sustainable: Lithuania compared to the EU, Entrepreneurship and Sustainability Issues 1(3): 134-142. DOI: http://dx.doi.org/10.9770/jesi.2014.1.3(2) 
The International Journal

ENTREPRENEURSHIP AND SUSTAINABILITY ISSUES

ISSN 2345-0282 (online) http://jssidoi.org/jesi/

2017 Volume 4 Number 4 (June)

http://doi.org/10.9770/jesi.2017.4.4(4)

Wartick, S. L.; Cochran, P. L. 1985. The Evolution of the Corporate Social Performance Model, Academy of Management Review 10(4): 758-769.

Weiss, J. W. 1994. Business Ethics: A Managerial, Stakeholder Approach. Belmont, Calif.: Wadsworth Publishing Co.

Wood, D. J. 1991. Corporate Social Performance Revisited, Academy of Management Review 16(4): 691-718.

Wu, M. 2006. Corporate Social Performance, Corporate Financial Performance and Firm Size: a Meta-Analysis, Journal of American Academy of Business 8(1): 163-171.

Miriam Jankalova is an associate professor. She is a lecturer, author, researcher and consultant, specializing in the areas of Business Excellence, Quality Management and Accounting. She is university teacher at the University of Žilina and her research is interested in Sustainability, Quality Management and Business Excellence. Her publication activities involve articles, textbooks and monographs on such area. She is member of many scientific boards and professional committees. She works also as a certified court translator (German Slovak).

ORCID ID: orcid.org/0000-0001-7260-5787; RESEARCHER ID: P-1191-2016

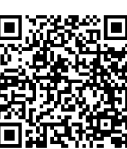

Radoslav Jankal is an associate professor. He is a lecturer, author, researcher and consultant, specializing in the areas of Strategic Management, Quality Management and Business Ethic. He is university teacher at the University of Žilina and his research is interested in Sustainability, Quality Management and Business Ethic. His publication activities involve articles, textbooks and monographs on such area. $\mathrm{He}$ is member of many scientific boards.

ORCID ID: orcid.org/0000-0001-6447-1651； RESEARCHER ID: P-1044-2016

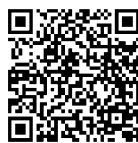

Copyright (C) 2017 by author(s) and VsI Entrepreneurship and Sustainability Center This work is licensed under the Creative Commons Attribution International License (CC BY). http://creativecommons.org/licenses/by/4.0/

CC) (7) Open Access 